\title{
Development and Validation of an Analytical Method for Residues of Organochlorine, Fenopropathrin and Poly Chlorinated Biphnyl Compounds in Fatty Food
}

\author{
Emad Atala, Sanaa A.M. El-Sawi, Abir ElGohary and Ali Ali Mahmoud \\ Central Lab of Residue Analysis of Pesticides and Heavy Metals in Food, \\ Agricultural Research Center, Ministry of Agriculture,Egypt \\ Corresponding author: Ali Ali Mahmoud, e-mail Dralialimahmoud44@yahoo.com
}

\begin{abstract}
A multi-residue method for the quantification of 9 organochlorine pesticides, one synthetic pyrithroid and 7 members of PCBs compounds residues in fish is described. The method involves the application of a modified pesticide manual procedure followed by GC-ECD (Gas Chromatography coupled with Electron Capture Detector) analysis. The method is validated according to the European Union SANCO/12495/2011 guidelines and Pesticide Manual of Analytical methods. The validation levels were $0.01 ; 0.04$; and $0.2 \mathrm{mg} / \mathrm{kg}$ for organochlorines except fenopropathrin (a synthetic pyrithroid insecticide) which has been validated at the concentration of $0.02,0.08$ and $0.4 \mathrm{mg} / \mathrm{kg}$ and for PCBs at $0.005,0.02$ and $0.1 \mathrm{mg} / \mathrm{kg}$. Acceptable values were obtained for the following parameters: limit of detection LOD (ranged between $0.003-0.009 \mathrm{mg} / \mathrm{kg}$ for organochlorine pesticides and $0.002 \mathrm{mg} / \mathrm{kg}$ for PCB's) and limit of quantification (LOQ) $(0.005 \mathrm{mg} / \mathrm{kg}$ for PCB's and in the range of $0.01-0.02 \mathrm{mg} / \mathrm{kg}$ for organochlorine compounds). The recovery percentages ranged between 70 and $120 \%$, and the measurement uncertainty tests was $\pm 40.0 \%$. The method showed to be linear from the LOQ up to the maximum level; $0.1 \mathrm{mg} / \mathrm{kg}$ for PCB's and in the range of $0.2-0.4 \mathrm{mg} / \mathrm{kg}$ for organochlorine compounds. These results demonstrate the applicability of this method in the routine practice for detecting the residues of such compounds in fatty food.
\end{abstract}

Key words: validation, organochlorines, PCBs, fatty foods

\section{INTRODUCTION}

Persistent organic pollutants (POPs) are toxic chemicals that are resistant to degradation in the environment. Due to their fat solubility and resistance to biological degradation, ingestion of certain classes of POPs by animals leads to bioaccumulation throughout their livers, generally in the fatty tissues, and to biomagnifications in the food chain (Gioia et al., 2013; Safe, 1994). Among the POPs, organochlorine pesticides (OCPs) and polychlorinated biphenyls (PCBs) are highly prevalent in vertebrates. The majority of POPs, such as PCBs and OCPs, are currently banned from use and are no longer produced or used around the world; therefore, their levels have been constantly declining through the years (Addison et al., 2013; Ryan et al., 2013; Schuster et al., 2011). Nevertheless, relevant amounts of these pollutants still persist in the environment, and certain species, specially those top predators, are especially contaminated (Bourgeon et al., 2013), and it has been described that these pollutants lead to adverse health effects on living beings (Hamlin and Guillette, 2010).

Pesticides reach aquatic ecosystems by direct application, spray drift, aerial spraying, erosion and runoff from factories and sewage. The contamination of water sources is a major source of concern since it is the habitat of fish and other aquatic organisms such as mussels, oysters, prawns and lobsters. Pesticides end up in the tissue of aquatic organisms and bioaccumulates with time (Jiries et al., 2002). Fish consumption could be therefore 
considered as one of the major sources of human exposure to all environmental contaminants (EFSA, 2005; Storelli, 2008). OC pesticides are ubiquitous anthropogenic contaminants that are persist in the environment; accumulate in fatty tissues and increase in concentration as they move up the food chain (WHO, 1999). Due to their lipophilic nature they accumulate along trophic levels and induce multiple adverse effects in many organisms (Fleming et al., 2006). Although the production and use of many types of OCs have been severely limited in many countries including Egypt, they are, nevertheless, still being used unofficially in large quantities in many parts of the world, and in other developing countries because of their effectiveness as pesticides and their relatively low cost. OCs were detected in fresh water fish in previous studies in Egypt by Salah El-Dien and Nasr (2004). The probable sources of this pesticide group originated from previous or illegal use.

Polychlorinated biphenyls (PCBs) were commercially produced as complex mixtures containing multiple isomers at different degrees of chlorination. Today, PCBs can still be released into the environment from poorly maintained hazardous waste sites that contain PCBs; illegal or improper dumping of PCB wastes; leaks or releases from electrical transformers containing PCBs (ATSDR, 2002). Some PCB congeners elicit a divers spectrum of toxic and biochemical responses including body weight loss, immunotoxicity (Sormo et al., 2009) and induction of gene expression (El Nemr et al., 2003). Because of the dangerous effect of the presence of OC and PCBs in fish tissues on human health a simple method for the determination of these compounds residues was evaluated.

\section{MATERIALS AND METHODS Standards and reagents}

Organochlorine pesticides, fenopropathrin and PCBs reference standards were purchased from Dr. Ehrensdorfer (Augsburg, Germany), with purity of $>95 \%$ and they were used to prepare stock and diluted solutions. Stock solutions of reference standard of concentration $1000 \mu \mathrm{g} / \mathrm{ml}$ were prepared in toluene and kept at $4 \pm 2{ }^{\circ} \mathrm{C}$. Spiking mixture standard solutions were prepared for fatty food analysis at concentration levels as shown in $\operatorname{Tables}(1$ and 2$)$. Spiking mixture solutions of PCB's and organochlorine pesticides can be prepared once a year.

Working standard of Aldrin with concentration of $0.1 \mu \mathrm{g} / \mathrm{ml}$ was prepared in n-hexane/ acetone (9:1) solution and it was used as an injection standard for GC- ECD.

The solvents used were aceton, hexane, petroleum ether, benzene, ethyl acetate and acetonitrile. Florsil, anhydrous sodium sulphate and sodium chloride were also used. All the reagents were of analytical (HPLC) grade supplied by BDH, London, UK. Before use; sodium sulphate was heated at 650 ${ }^{\circ} \mathrm{C}$ for $4 \mathrm{~h}$ and kept in a desiccator. Distilled water was obtained with a Milli-Q system (Millipore, Bedford, MA, USA). 
Table 1: The concentration levels of organochlorines and fenopropathrin insecticides spiked to fatty food samples

\begin{tabular}{|c|c|c|c|c|c|}
\hline \multicolumn{6}{|c|}{ Organochlorines and fenopropathern pesticides } \\
\hline \multicolumn{3}{|c|}{ Mixture 1} & \multicolumn{3}{|c|}{ Mixture 2} \\
\hline Compound & $\begin{array}{l}\text { Spike } \\
\text { Conc. } \\
\text { ( } \mu \mathrm{g} / \mathrm{ml})\end{array}$ & $\begin{array}{l}\text { Expected } \\
\text { Spike Level } \\
\text { (mg/kg) } \\
\text { on } 25 \mathrm{~g}\end{array}$ & Compound & $\begin{array}{l}\text { Spike Conc. } \\
(\mu \mathrm{g} / \mathrm{ml})\end{array}$ & $\begin{array}{l}\text { Expected Spike } \\
\text { Level }(\mathrm{mg} / \mathrm{kg}) \\
\text { on } 25 \mathrm{~g}\end{array}$ \\
\hline $\mathrm{HCH}$-alpha & 1 & 0.04 & HCB & 0.5 & 0.02 \\
\hline $\mathrm{HCH}-\mathrm{g}$ (Lindane) & 1 & 0.04 & $\mathrm{HCH}$-beta & 1 & 0.04 \\
\hline Heptachlor & 1 & 0.04 & $\mathrm{HCH}$-delta & 1 & 0.04 \\
\hline $\begin{array}{l}\text { Heptachlor-exo- } \\
\text { Epoxide }\end{array}$ & 1 & 0.04 & Endouslfan-alpha & 1 & 0.04 \\
\hline DDE-p,p’ & 1 & 0.04 & Dieldrin & 1 & 0.04 \\
\hline Endrin & 1 & 0.04 & EndousIfan-beta & 1 & 0.04 \\
\hline DDT-p,p & 5 & 0.2 & Endosulfan Sulfate* & 5 & 0.2 \\
\hline Fenpropathrin & 2 & 0.08 & $\begin{array}{l}\text { Heptachlor-endo- } \\
\text { epoxide }\end{array}$ & 1 & 0.04 \\
\hline Esfenvalerate & 5 & 0.2 & & & \\
\hline Deltamethrin & 5 & 0.2 & & & \\
\hline
\end{tabular}

Table 2: The concentration levels of PCBs compounds spiked to fatty food samples

\begin{tabular}{lccc}
\hline Name & Spike conc. $(\boldsymbol{\mu g} / \mathbf{m l})$ & $\begin{array}{c}\text { Expected Spike } \\
\text { Level on } \mathbf{2 . 5} \mathbf{~ g} \\
(\mathbf{m g} / \mathbf{k g})\end{array}$ & $\begin{array}{c}\text { Expected Spike Level on } \\
\mathbf{2 5} \mathbf{~ g}(\mathbf{m g} / \mathbf{k g})\end{array}$ \\
\hline PCB's 28 & 0.05 & 0.02 & 0.002 \\
PCB's 52 & 0.05 & 0.02 & 0.002 \\
PCB's 101 & 0.05 & 0.02 & 0.002 \\
PCB's 118 & 0.05 & 0.02 & 0.002 \\
PCB's 153 & 0.05 & 0.02 & 0.002 \\
PCB's 138 & 0.05 & 0.02 & 0.002 \\
PCB's 180 & 0.05 & 0.02 & 0.002 \\
\hline
\end{tabular}

\section{Sample extraction}

Twenty five grams (W) of edible fish or animal tissue was placed into blender jar with $50 \mathrm{~g}$ sodium sulphate, blended and mixed with spatula until sample and sodium sulphate were well mixed. The sides of blender jar were scraped down and broke up caked material with spatula. For spike sample, $1 \mathrm{ml}$ spike solution was added on $25 \mathrm{~g}$ sample that was proved to be free of PCB's and organochlorine pesticides. $150 \mathrm{ml}$ petroleum ether was added and blended at high speed for $2 \mathrm{~min}$. Petroleum ether supernatant decanted and filtered under suction through buchner fitted with filter paper. The sides were scraped down of blender jar and broke up caked material with spatula.

The residue was re-extracted in blender jar with two $100 \mathrm{ml}$ portions of petroleum ether, blended for 2 min each time. After 1 min blending, bender was stopped material was scraped from sides of blending jar and broke up caked material with spatula. Sides of blender jar were scraped down and broke up 
caked material between extractions. Petroleum ether was decanted through buchner funnel and combined with first extract. After last blending, residue from blender jar was transferred into the buchner funnel, blender jar and material were rinsed in buchner with three $25 \mathrm{ml}$ portions of petroleum ether and filtration was continued through the same buchner.

Combined extracts were poured the buchner funnel was rinsed with 25 $\mathrm{ml}$ petroleum ether and the filtrate was collected through anhydrous sodium sulphate in pre-weighed $500 \mathrm{ml}$ flask. Petroleum ether from combined extracts was evaporated at $35-40{ }^{\circ} \mathrm{C}$ on rotary evaporator. The $500 \mathrm{ml}$ flask after evaporation was weighed and the weight of the extracted fat was calculated $\left(W_{1}\right)$. If the total amount of fat is more than $3 \mathrm{~g}, 2.5 \mathrm{~g}\left(\mathrm{~W}_{2}\right)$ fat is taken only for liquid-liquid partitioning. If the extracted fat weight is less than $3 \mathrm{~g}$, all the fat was taken for liquid-liquid partitioning should follow the adjusted formula $\left(\mathrm{W}_{1} / \mathrm{W}_{2}=1\right)$ (Pesticide Analytical Manual, 1994) (PAM).

\section{Modifications to the PAM method}

Rotary evaporator and air blow are used instead of Kurdana- Danish. Mixture of hexane/benzene/ethyl acetate is used to elute organochlorine pesticides instead of petroleum ether/ethyl ether mixture.

\section{Liquid-liquid partitioning}

The extracted fat was quantitavely transferred 3 times with $5 \mathrm{ml}$ petroleum ether in $100 \mathrm{ml}$ separatory funnel. Thirty $\mathrm{ml}$ acetonitrile saturated with petroleum ether were added, shaked vigorously for 1 min till the layers are separated, and drain acetonitrile (lower layer) into one liter separatory funnel containing $600 \mathrm{ml}$ de-ionized water, $40 \mathrm{ml}$ saturated sodium chloride solution, and $100 \mathrm{ml}$ petroleum ether. Petroleum ether solution was extracted in $100 \mathrm{ml}$ separatory funnel with three additional $30 \mathrm{ml}$ portions of acetonitrile saturated with petroleum ether, shaked vigorously for 1 min each time, and all acetonitrile extracts were combined in the one liter separatory funnel. The separatory funnel was shaked gently for $1 \mathrm{~min}$, let layers to separate and drain the aqueous layer (lower layer) into second one liter separatory funnel. A hundrad $\mathrm{ml}$ petroleum ether was added to second one liter separatory funnel, shaked vigorously for 15 seconds and let layers to separate. Aqueous layer was discarded and the petroleum ether layer was combined with that in the original one liter separatory funnel. Petroleum ether layer was washed with two $100 \mathrm{ml}$ portions de-ionized water. Washings were discarded and petroleum ether layer was drained through anhydrous sodium sulphate supported on washed cotton with petroleum ether in funnel on receiving flask. Evaporation was done on rotary evaporator to dryness at $35-40{ }^{\circ} \mathrm{C}$. The residue was dissolved in $10 \mathrm{ml}$ hexane/acetone (9:1) (V1); aliquot $\left(\mathrm{V}_{2}\right)$ of $2 \mathrm{ml}$ for organochlorine pesticide clean up. For PCB's, clean up aliquot of $5 \mathrm{ml}\left(\mathrm{V}_{2}\right)$ was taken, evaporated, and re-dissolved in $5 \mathrm{ml}$ petroleum ether.

\section{Florisil Column}

\section{Organochlorine pesticides and PCB's clean up}

The chromatographic column was placed (length $40 \mathrm{~cm}$ and internal diameter $16 \mathrm{~mm}$ ) in the following order, glass wool plug, $10 \mathrm{~g}$ activated florisil 
and $2 \mathrm{~cm}$ height of anhydrous sodium sulphate on the top of florisil. Florisil and sodium sulphate were settled by tapping the column. The column was pre-wet with $50 \mathrm{ml}$ hexane. $250 \mathrm{ml}$ receiving flask was placed under the column to receive elutes. Sample extract solution was transferred to the column and the flow was adjusted to about $2.5 \mathrm{ml} / \mathrm{min}$. The column was eluted with $50 \mathrm{ml}$ (elute I) and $25 \mathrm{ml}$ (elute II). The two elutes were combined in $250 \mathrm{ml}$ flask, evaporated on rotary evaporator to about $2 \mathrm{ml}$ at $35-40{ }^{\circ} \mathrm{C}$. Evaporation was continued by air just to dryness. The residues were re-dissolved in $2 \mathrm{ml}\left(\mathbf{V}_{\mathbf{3}}\right)$ and the injection standard was immediately done after the evaporation is completed and $1 \mu \mathrm{l}$ was injected into GC-ECD system. The same steps were done for PCB's clean up except of using petroleum ether for Pre-wet and the residues were dissolved in $2 \mathrm{ml}\left(\mathbf{V}_{3}\right)$ hexane/acetone (9:1) and sonnicated for 1 minute before injection.

\section{GC conditions}

Gas Chromatograph HP 6890 equipped with two electron capture detectors was used and the instrument was conditioned as follow:

- Injector temp $=225^{\circ} \mathrm{C} \quad$ Detector temp $=300{ }^{\circ} \mathrm{C}$

- Flow rate of nitrogen: $1.3 \mathrm{ml} / \mathrm{min}$ carrier, total flow (carrier + makeup):

$55 \mathrm{ml} / \mathrm{min}$.

- Septum purge: $3 \mathrm{ml} / \mathrm{min}$, purge flow $50 \mathrm{ml} / \mathrm{min}$, purge time $0.7 \mathrm{~min}$.

\section{Oven program}

The oven was programmed as follows:

\begin{tabular}{cccc}
\hline Initial temp: $90^{\circ} \mathrm{C}$ & & Initial time: & 2 min \\
\hline \multirow{2}{*}{ Level } & Rate & Temp & Time \\
$(1)$ & $\left({ }^{\circ} \mathrm{C} / \mathrm{min}\right)$ & $\left({ }^{\circ} \mathrm{C}\right)$ & $(\mathrm{min})$ \\
$(2)$ & 20 & 150 & 0 \\
\hline
\end{tabular}

\section{Capillary columns}

Two different capillary columns were used and they were:

a) Agilent Technologies: HP-PAS5

Column ID: $0.32 \mathrm{~mm}$, Film thickness: 0.52 um, Column length: $25 \mathrm{~m}$

b) Agilent Technologies: DB-1701P

Column ID: 0.32 um, Film thickness: 0.25 um, Column length: $25 \mathrm{~m}$

\section{Calculations}

The analyte concentration in sample $(\mathrm{Cs})(\mathrm{mg} / \mathrm{kg})$ is calculated as follows:

Where:

$$
C s=C i \times \frac{V_{1}}{V_{2}} \times \frac{V_{3}}{W} \times \frac{W_{1}}{W_{2}}
$$

$\mathbf{C}_{\mathbf{i}}=$ Concentration in injection $(\mu \mathrm{g} / \mathrm{ml})$.

$\mathbf{V}_{1}=$ Dilution volume after partitioning.

$\mathbf{V}_{\mathbf{2}}=$ Volume taken for clean up (ml).

$\mathbf{V}_{\mathbf{3}}=$ Final dilution volume $(\mathrm{ml})$.

$\mathbf{W}=$ Weight of original sample.

$\mathbf{W}_{\mathbf{1}}=$ Weight of extracted fat $(\mathrm{g})$. 
$\mathbf{W}_{\mathbf{2}}=$ Weight of fat taken for liquid-liquid partitioning $(\mathrm{g})$.

This equation is used when the weight of the extracted fat from the sample is greater than $3 \mathrm{~g}$.

\section{Organochlorine and fenopropathrin pesticides calculations}

Calculations of organochlorine pesticides were based on "injection stranded calculations" method and one level calibration curve.

In case of the extracted weight of fat is less than $3 \mathrm{~g}$, all the extracted fat will be taken for liquid-liquid partitioning $(\mathrm{W} 1 / \mathrm{W} 2=1)$ and dilution volume after partitioning is $10 \mathrm{ml}(\mathrm{V} 1=10 \mathrm{ml})$, the volume was taken for clean up is $2 \mathrm{ml}$ (V2 $=2 \mathrm{ml})$, the final dilution volume is $2 \mathrm{ml}(\mathrm{V} 3=2 \mathrm{ml})$ and the weight of original sample is $25 \mathrm{~g}(\mathrm{~W}=25 \mathrm{~g})$.

So, the equation used for calculations can be summarized as follows:

$$
\begin{aligned}
& \text { OCh. (Fish samples) } \\
& C s=C i \times 0.4
\end{aligned}
$$

Where; $C_{i}=$ Concentration in injection $(\mu \mathrm{g} / \mathrm{ml})$.

\section{PCB's calculations}

Calculations of resulted concentrations of residues are based on multilevel calibration curve.

If we assume that the extracted fat is less than $3 \mathrm{~g}$, so all the extracted fat will be taken for liquid-liquid partitioning must meet the equation $\left(\mathrm{W}_{1} / \mathrm{W}_{2}=1\right)$ and dilution volume after partitioning is $10 \mathrm{ml}\left(\mathrm{V}_{1}=10 \mathrm{ml}\right)$, the volume taken for clean up is $5 \mathrm{ml}\left(\mathrm{V}_{1}=5 \mathrm{ml}\right)$, the final dilution volume is $2 \mathrm{ml}\left(\mathrm{V}_{3}=2 \mathrm{ml}\right)$ and the weight of original sample is $25 \mathrm{~g}(\mathrm{~W}=25 \mathrm{~g})$.

So the equation used for calculations can be summarized as follows;

PCB's (Fish samples)

$$
C s=C i \times 0.16
$$

Where; $C_{i} \quad=$ Concentration in injection $(\mu \mathrm{g} / \mathrm{ml})$.

\section{RESULTS AND DISCUSSIONS}

The validation study was carried out using the blackcurrant samples that were previously checked to be free of the pesticides of interest. The recoveries were determined in six repetition and the three spiking levels ranged between 0.01 to $0.4 \mathrm{mg} / \mathrm{kg}$. The samples were spiked before proceeding with the sample preparation. Average recovery and relative standard deviation (RSD), values per spiking level and the overall value were calculated for each pesticide. The results were assessed for compliance with the European Union guidelines SANCO/12495/2011, according to which the average recovery should be in the range of $70-120 \%$ with RSD less or equal to $20 \%$ (SANCO/12495, 2011). The limit of quantification (LOQ) was set at the least spiking concentration that has been validated with satisfactory recovery and precision parameters. 


\section{Recovery tests}

The recovery of organochlorine pesticides and PCB's were tested by performing repeated spike fish samples (Repeatability) at different concentration levels. The recovery percentage and relative standard deviation on each level were calculated. The results of the recovery percentages of tested pesticides and PCBs are presented in Table 3.

Table 3: The recovery percentages of the tested pesticides and PCBs spiked and analyzed from fish samples

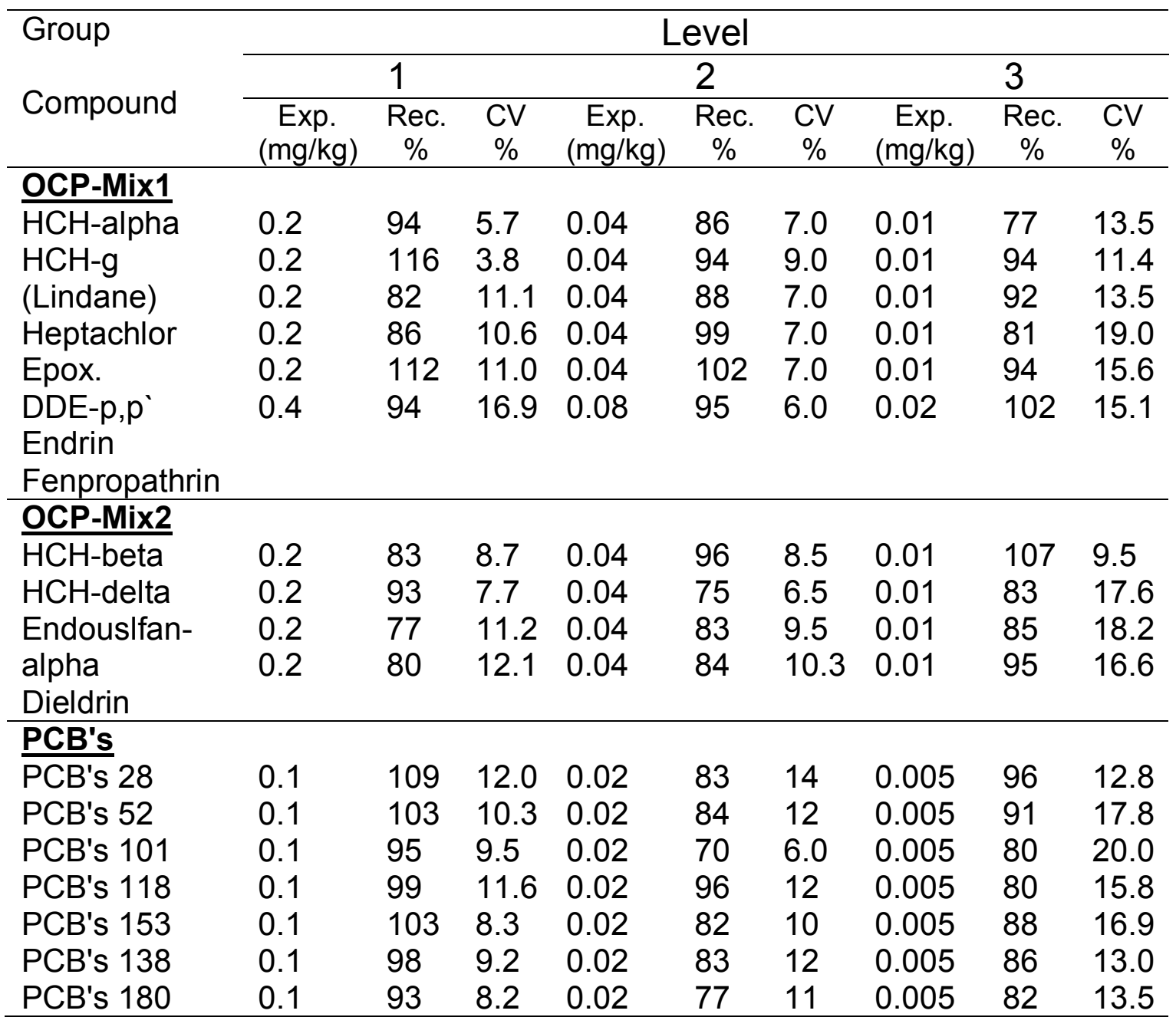

\section{Limit of detection (LOD)}

Limit of detection is the minimum concentration of analyte in the test sample that can be measured with a stated probability that the analyte is present at a concentration above that in the blank sample. The limit of detection is estimated as $3 \mathrm{~s}$ of sample blanks fortified at the least acceptable concentration level. The limit of detection (LD) ranged between 0.003-0.009 $\mathrm{mg} / \mathrm{kg}$ for organochlorine and fenopropathrin pesticides and $0.002 \mathrm{mg} / \mathrm{kg}$ for PCB's (Table 4). 


\section{Limit of quantitation (LOQ)}

The limit of quantitation is the minimum concentration of analyte in the test sample that can be determined with acceptable precision (repeatability) and recovery under the stated conditions of the test. The lowest practical limit of quantitation was estimated by using repeated spiked samples at about the expected lowest quantitation level on fish samples. The limit of quantitation (LOQ) was $0.005 \mathrm{mg} / \mathrm{kg}$ for PCB's and in the range of $0.01-0.02 \mathrm{mg} / \mathrm{kg}$ for organochlorine compounds.

Table 4: The limit of detection (LOD) of PCB's and organochlorine pesticides.

\begin{tabular}{lccc}
\hline \multicolumn{1}{c}{ Group } & $\begin{array}{c}\text { Expected } \\
\text { (mg/kg) }\end{array}$ & $\begin{array}{c}\text { Signal to } \\
\text { noise(s) } \\
\text { (mg/kg) }\end{array}$ & $\begin{array}{l}\text { LD (3s) } \\
(\mathrm{mg} / \mathrm{kg})\end{array}$ \\
\hline OCP-Mix1 & & & \\
HCH-alpha & 0.01 & 0.0010 & 0.003 \\
HCH-g (Lindane) & 0.01 & 0.0011 & 0.003 \\
Heptachlor Epox. & 0.01 & 0.0012 & 0.004 \\
DDE-p,p & 0.01 & 0.0015 & 0.005 \\
Endrin & 0.01 & 0.0015 & 0.005 \\
Fenpropathrin & 0.02 & 0.0031 & 0.009 \\
\hline OCP-Mix2 & & & \\
HCH-beta & 0.01 & 0.0010 & 0.003 \\
HCH-delta & 0.01 & 0.0015 & 0.004 \\
Endouslfan-alpha & 0.01 & 0.0015 & 0.005 \\
Dieldrin & 0.01 & 0.0016 & 0.005 \\
\hline PCB's & & & \\
PCB's 28 & 0.005 & 0.0006 & 0.002 \\
PCB's 52 & 0.005 & 0.0008 & 0.002 \\
PCB's 101 & 0.005 & 0.0008 & 0.002 \\
PCB's 118 & 0.005 & 0.0006 & 0.002 \\
PCB's 138 & 0.005 & 0.0006 & 0.002 \\
PCB's 153 & 0.005 & 0.0007 & 0.002 \\
PCB's 180 & 0.005 & 0.0006 & 0.002 \\
\hline
\end{tabular}

\section{Linearity}

\section{Linear range}

For quantitative analysis, the range of analyte concentrations over which the method may apply was determined. For organochlorine pesticides, the calculations are based on internal standard calculations method.

For PCB's the calculations are based on five levels calibration curve $(0.01,0.03$, $0.05,0.1$ and $0.2 \mu \mathrm{g} / \mathrm{ml}$ ). No internal standard was used. The correlation coefficient was found to be greater than 0.999 . The calibration curve must be done with every set of samples.

\section{Method Linearity}

Method linearity was tested by performing recovery tests at different three levels on fish samples. The method showed to be linear from the LOQ up 
to the maximum level; $0.1 \mathrm{mg} / \mathrm{kg}$ for PCB's and in the range of $0.2-0.4 \mathrm{mg} / \mathrm{kg}$ for organochlorine compounds. Figure 3 shows an example of each tested group (mix.1, mix.2 and PCBs). It illustrate that the calculated correlations were greater than 0.99 (Fig. 1).

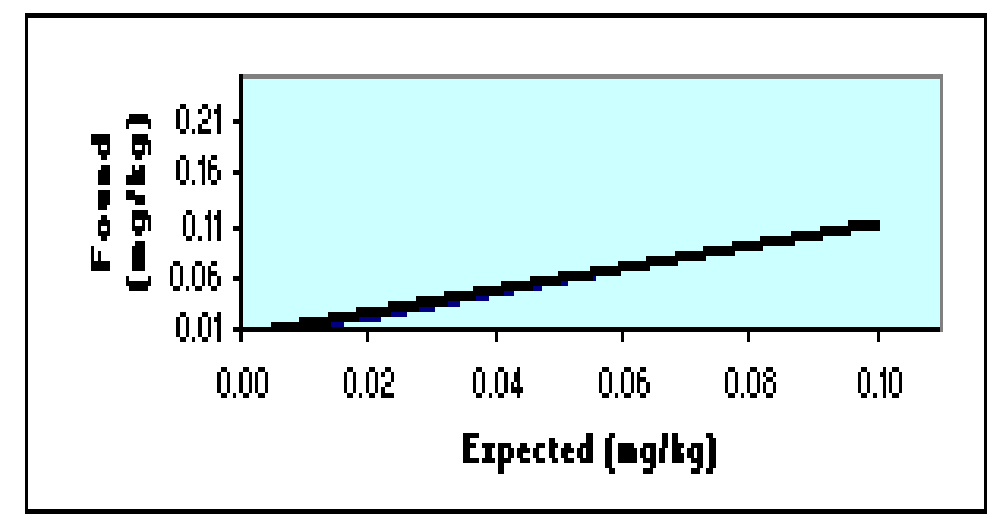

(a) PCBs

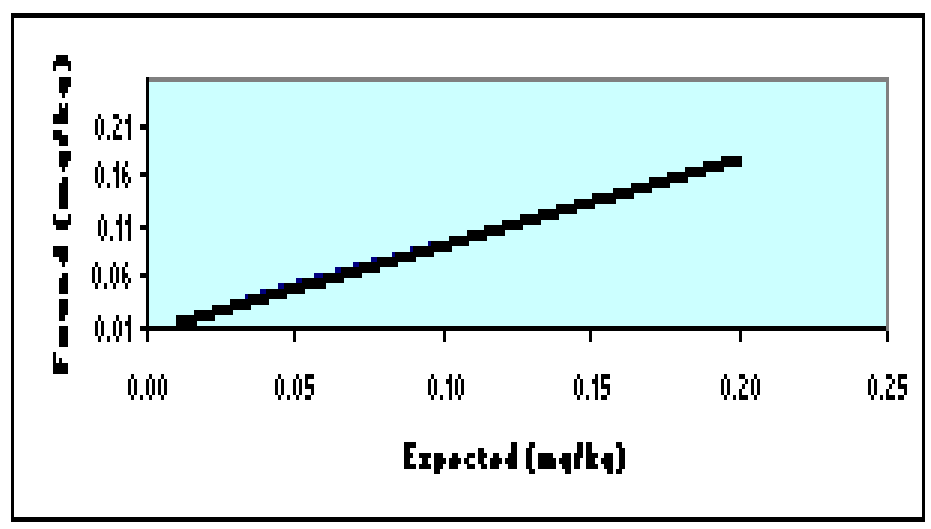

(b) Mix.1

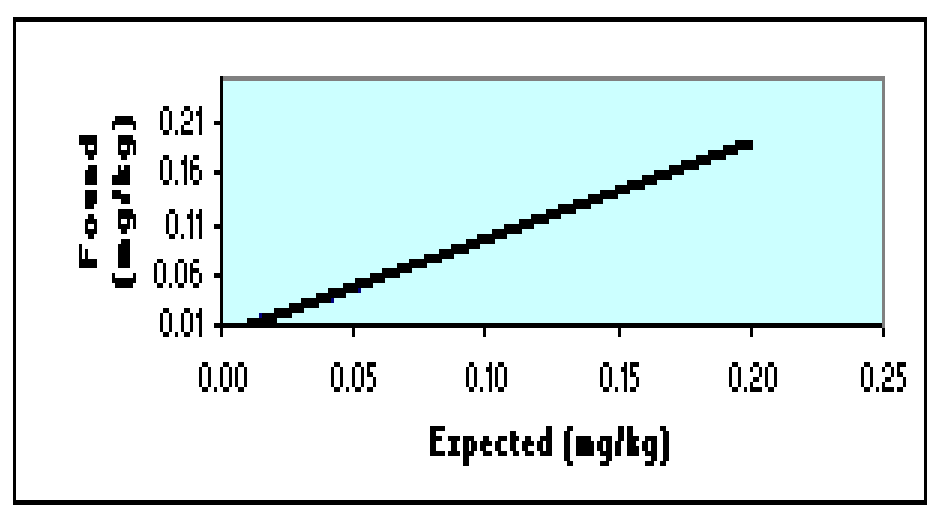

(c) Mix.2

Figure 1: The linear curves of certain compounds as an example of these tested compounds (a: an example of mix.1, b: an example of mix.2 and c: an example of PCBs). 


\section{Accuracy}

Accuracy expresses the closeness of a result to a true value. Accuracy is expressed in terms of two components: "Trueness" and "Precision"

\section{Trueness}

The trueness of a method is an expression of how close the mean of a set of results (produced by the method) is to the true value. To check trueness of the method, spiked samples are used at different levels on fish samples. Bias expressed as absolute relative difference percentage (RD\%) was found to be within the codex criteria.

Table 5: The results of trueness calculations.

\begin{tabular}{lccccccccc}
\hline \multirow{2}{*}{$\begin{array}{c}\text { Group } \\
\text { Compound }\end{array}$} & \multicolumn{7}{c}{1} & \multicolumn{7}{c}{ Level } & & & \\
\cline { 2 - 9 } & $\begin{array}{c}\text { Exp. } \\
\text { mg/kg }\end{array}$ & $\begin{array}{c}\text { Found } \\
\text { mg/kg }\end{array}$ & $\begin{array}{c}\text { Bias } \\
\%\end{array}$ & $\begin{array}{c}\text { Exp. } \\
\text { mg/kg }\end{array}$ & $\begin{array}{c}\text { Found } \\
\text { mg/kg }\end{array}$ & $\begin{array}{c}\text { Bias } \\
\%\end{array}$ & $\begin{array}{c}\text { Exp. } \\
\text { mg/kg }\end{array}$ & $\begin{array}{c}\text { Found } \\
\text { mg/kg }\end{array}$ & Bias \\
\hline OCP-Mix1 & & & & & & & & & \\
\hline HCH-alpha & 0.2 & 0.187 & $7 \%$ & 0.04 & 0.034 & $15 \%$ & 0.01 & 0.0077 & $23 \%$ \\
HCH-g & 0.2 & 0.231 & $16 \%$ & 0.04 & 0.038 & $5 \%$ & 0.01 & 0.0094 & $6 \%$ \\
(Lindane) & 0.2 & 0.163 & $19 \%$ & 0.04 & 0.035 & $13 \%$ & 0.01 & 0.0092 & $8 \%$ \\
Heptachlor & 0.2 & 0.172 & $14 \%$ & 0.04 & 0.04 & $0 \%$ & 0.01 & 0.0081 & $19 \%$ \\
Epox. & 0.2 & 0.225 & $13 \%$ & 0.04 & 0.041 & $3 \%$ & 0.01 & 0.0094 & $6 \%$ \\
DDE-p,p & 0.4 & 0.375 & $6 \%$ & 0.08 & 0.076 & $5 \%$ & 0.02 & 0.02 & $0 \%$ \\
Endrin & & & & & & & & & \\
Fenpropathrin & & & & & & & & & \\
OCP-Mix2 & & & & & & & & & \\
HCH-beta & 0.2 & 0.167 & $17 \%$ & 0.04 & 0.038 & $5 \%$ & 0.01 & 0.011 & $10 \%$ \\
HCH-delta & 0.2 & 0.185 & $8 \%$ & 0.04 & 0.03 & $25 \%$ & 0.01 & 0.0083 & $17 \%$ \\
Endouslfan- & 0.2 & 0.154 & $23 \%$ & 0.04 & 0.033 & $18 \%$ & 0.01 & 0.0085 & $15 \%$ \\
alpha & 0.2 & 0.16 & $20 \%$ & 0.04 & 0.034 & $15 \%$ & 0.01 & 0.0095 & $5 \%$ \\
Dieldrin & & & & & & & & & \\
PCB's & & & & & & & & & \\
\hline PCB's 28 & 0.1 & 0.109 & $9 \%$ & 0.02 & 0.017 & $15 \%$ & 0.005 & 0.0048 & $4 \%$ \\
PCB's 52 & 0.1 & 0.103 & $3 \%$ & 0.02 & 0.017 & $15 \%$ & 0.005 & 0.0045 & $10 \%$ \\
PCB's 101 & 0.1 & 0.095 & $5 \%$ & 0.02 & 0.014 & $30 \%$ & 0.005 & 0.004 & $20 \%$ \\
PCB's 118 & 0.1 & 0.099 & $1 \%$ & 0.02 & 0.019 & $5 \%$ & 0.005 & 0.004 & $20 \%$ \\
PCB's 153 & 0.1 & 0.103 & $3 \%$ & 0.02 & 0.016 & $20 \%$ & 0.005 & 0.0044 & $12 \%$ \\
PCB's 138 & 0.1 & 0.098 & $2 \%$ & 0.02 & 0.017 & $15 \%$ & 0.005 & 0.0043 & $14 \%$ \\
PCB's 180 & 0.1 & 0.093 & $7 \%$ & 0.02 & 0.015 & $25 \%$ & 0.005 & 0.0041 & $18 \%$ \\
\hline
\end{tabular}

Trueness was also tested by repeating FAPAS proficiency test which has been analyzed by two different chemists for determination of certain selected PCB's and organochlorine pesticides as seen in Table 6. 
Table 6: The accepted recovery percentages of certain selected compounds according to codex criteria.

\begin{tabular}{lccccc}
\hline \multirow{2}{*}{$\begin{array}{c}\text { Selected } \\
\text { Compound }\end{array}$} & $\begin{array}{c}\text { Assigned } \\
\text { value } \\
(\mathbf{m g} / \mathbf{k g})\end{array}$ & $\begin{array}{c}\text { Found } \\
\mathbf{( m g / k g )}\end{array}$ & $\begin{array}{c}\text { Trueness } \\
\text { (Recovery \%) }\end{array}$ & $\begin{array}{c}\text { Found } \\
(\mathbf{m g} / \mathbf{k g})\end{array}$ & $\begin{array}{c}\text { Trueness } \\
\text { (Recovery \%) }\end{array}$ \\
\cline { 3 - 6 } & 0.0278 & 0.020 & $72 \%$ & 0.0270 & $97 \%$ \\
alpha -HCH & 0.0544 & 0.0448 & $82 \%$ & 0.0570 & $105 \%$ \\
PCB'drin & 0.0379 & 0.0385 & $102 \%$ & 0.0320 & $84 \%$ \\
PCB's 153 & 0.0803 & 0.0840 & $105 \%$ & 0.0642 & $80 \%$ \\
\hline
\end{tabular}

\section{Precision}

Precision is a measure of how close results are to one another. The two most common precision measures are (repeatability) and (reproducibility)

\section{Repeatability}

Qualitatively is the closeness of agreement between successive results obtained with the same method on identical test material, under the same conditions (same operator, apparatus and laboratory as well as short intervals of time) (ISO 3534-1). Repeatability experiments were done by fortification on fish samples at different levels.

The previous Table 3 shows the accepted recovery percentage and CV\%; except for fenpropathrin $(\mathrm{CV} \%=16.9 \%)$ at level one which exceeded the codex criteria (CV \%<15\% at $0.4 \mathrm{mg} / \mathrm{kg}$ level).

\section{Reproducibility}

Reproducibility is the precision under reproducibility conditions, i.e. conditions where test results are obtained with the same method on identical test items in different laboratories with different operators using different equipment. In this study, intra-laboratory reproducibility has only be considered. Spiking fish samples were analyzed by different analysts on several days. Reproducibility results are shown in Table 7.

\section{Measurement Uncertainty}

Parameter associated with the result of a measurement that characterises the dispersion of the values that could reasonably be attributed to the measurand. The parameter may be, for example, a standard deviation (or a given multiple of it), or the width of a confidence interval. For estimating the overall uncertainty, it may be necessary to take each source of uncertainty and treat it separately to obtain the contribution of each source. Each of the separate contributions to uncertainty is referred to as an uncertainty component. When expressed as a standard deviation an uncertainty component is known as standard uncertainty. The total uncertainty, combined standard uncertainty, equal to the positive square root of the sum of the squares of the individual uncertainty components. For most purposes in analytical chemistry, an expanded uncertainty, should be used. The expanded uncertainty provides an interval within which the value of the measured is believed to lie in a higher level of confidence. Expanded 
uncertainty is obtained by multiplying the combined uncertainty, by a coverage factor (k); for confidence level of $95 \% \mathrm{k}$ is equal to 2 (EURACHEM, 2000).

Table 7: Reproducibility tests of fish samples analyzed by different analysts on several days.

\begin{tabular}{lccc}
\hline \multicolumn{1}{c}{ Group } & $\begin{array}{c}\text { Expected } \\
\text { (mg/kg) }\end{array}$ & $\begin{array}{c}\text { Mean } \\
\text { Recovery } \\
(\mathrm{mg} / \mathrm{kg})\end{array}$ & CV\% \\
\hline OCP-Mix1 & & & \\
\hline HCH-alpha & 0.04 & $83 \%$ & $7.6 \%$ \\
HCH-g (Lindane) & 0.04 & $85 \%$ & $8.0 \%$ \\
Heptachlor Epox. & 0.04 & $72 \%$ & $8.2 \%$ \\
DDE-p,p & 0.04 & $87 \%$ & $19.2 \%$ \\
Endrin & 0.04 & $98 \%$ & $14.2 \%$ \\
Fenpropathrin & 0.08 & $76 \%$ & $19.3 \%$ \\
OCP-Mix2 & & & \\
HCH-beta & 0.04 & $79 \%$ & $13.0 \%$ \\
HCH-delta & 0.04 & $92 \%$ & $12.4 \%$ \\
Endouslfan-alpha & 0.04 & $80 \%$ & $11.1 \%$ \\
Dieldrin & 0.04 & $80 \%$ & $11.7 \%$ \\
PCB's & & & \\
PCB's 28 & 0.02 & $83 \%$ & $8.7 \%$ \\
PCB's 52 & 0.02 & $83 \%$ & $5.5 \%$ \\
PCB's 101 & 0.02 & $80 \%$ & $17.6 \%$ \\
PCB's 118 & 0.02 & $79 \%$ & $13.8 \%$ \\
PCB's 138 & 0.02 & $89 \%$ & $11.4 \%$ \\
PCB's 153 & 0.02 & $80 \%$ & $15.1 \%$ \\
PCB's 180 & 0.02 & & \\
\hline
\end{tabular}

The ISO Guide defines the uncertainty in terms of type A and type B;

Type A evaluation of uncertainty: method of evaluation of uncertainty by statistical analysis of series of observations.

Type B evaluation of uncertainty: method of evaluation of uncertainty by means other than statistical analysis of series of observations.

\section{Standard Uncertainty}

Validation studies were used to quantify different uncertainty components. The random effects were estimated as the relative standard deviation of repeated spike samples. Standard uncertainty due to repeatability experiments $\left(U_{\mathrm{r}}\right)$, expressed as relative standard deviation was found to be less than $14 \%$.

Standard uncertainty due to bias (recovery) experiments $\left(U_{R}\right)$, was estimated as relative standard deviation of the recovery of spike samples at different concentration levels. The spike samples were run during several days and by different analysts. Standard uncertainty due to recovery experiments 
expressed as relative standard deviation and that was found to be less than $20 \%$.

Standard uncertainty due to pipettes and volumetric flasks are not accounted for, since they are involved in recovery experiments.

The following equations were used for standard uncertainty calculations (Type A);

$$
\begin{aligned}
& S=\sqrt{\frac{\sum\left(x_{i}-\bar{x}\right)^{2}}{n-1}} \\
& R S d \%=\frac{S}{x} \times 100
\end{aligned}
$$

Where

$\mathrm{S}$, is the standard deviation

$\mathrm{RSd} \%$, relative standard deviation $\quad \bar{x}$, the average of $\mathrm{n}$ samples

\section{Combined Uncertainty $\left(\mathrm{U}_{\mathrm{C}}\right)$}

Combined uncertainty, is the positive square root of the sum of the squares of different uncertainty components which was found to be less than $21 \%$.

The following equation was used for combined uncertainty calculations

$$
U_{C}=\sqrt{\left(U_{r}\right)^{2}+\left(U_{R}\right)^{2}}
$$

\section{Expanded Uncertainty}

Table 8 represent the obtained expanded uncertainty which has been calculated by multiplying the combined uncertainty, by a coverage factor $(k)$, for confidence level of $95 \% \mathrm{k}$ is equal to 2 .

The expanded uncertainty (at $95 \%$ confidence level) was found to be less than $40 \%$. 
Table 8: The standard uncertainty due to repeatability (Ur), standard uncertainty due to reproducibility (UR), combined uncertainty (Ucomb) and expanded uncertainty (Uexp).

\begin{tabular}{lcccc}
\hline \multicolumn{1}{c}{ Group } & Ur & UR & Ucomb & Uexp \\
\multicolumn{1}{c}{ Compound } & & & & \\
\hline OCP-Mix1 & & & & \\
\hline HCH-alpha & & & & \\
HCH-g & & & & \\
(Lindane) & $7.3 \%$ & $8.1 \%$ & $10.9 \%$ & $22 \%$ \\
Heptachlor & $9.2 \%$ & $8.9 \%$ & $12.8 \%$ & $26 \%$ \\
Epox. & $7.0 \%$ & $7.2 \%$ & $10.0 \%$ & $20 \%$ \\
DDE-p,p & $6.8 \%$ & $6.8 \%$ & $9.6 \%$ & $19 \%$ \\
Endrin & $7.0 \%$ & $6.8 \%$ & $9.7 \%$ & $19 \%$ \\
Fenpropathrin & $6.0 \%$ & $19.3 \%$ & $20.2 \%$ & $40 \%$ \\
OCP-Mix2 & & & & \\
HCH-beta & & & & \\
HCH-delta & $8.5 \%$ & $13.3 \%$ & $15.8 \%$ & $32 \%$ \\
Endouslfan- & $6.5 \%$ & $12.4 \%$ & $14.0 \%$ & $28 \%$ \\
alpha & $9.5 \%$ & $11.1 \%$ & $14.6 \%$ & $29 \%$ \\
Dieldrin & $10.3 \%$ & $11.7 \%$ & $15.6 \%$ & $31 \%$ \\
PCB's & & & & \\
\hline PCB's 28 & $13.6 \%$ & $10.5 \%$ & $17.2 \%$ & $34 \%$ \\
PCB's 52 & $12.3 \%$ & $15.9 \%$ & $20.1 \%$ & $40 \%$ \\
PCB's 101 & $6.4 \%$ & $5.6 \%$ & $8.5 \%$ & $17 \%$ \\
PCB's 118 & $12.4 \%$ & $8.2 \%$ & $14.8 \%$ & $30 \%$ \\
PCB's 138 & $9.6 \%$ & $3.3 \%$ & $10.2 \%$ & $20 \%$ \\
PCB's 153 & $12.0 \%$ & $5.7 \%$ & $13.3 \%$ & $27 \%$ \\
PCB's 180 & $11.3 \%$ & $8.0 \%$ & $13.8 \%$ & $28 \%$ \\
\hline
\end{tabular}

\section{CONCLUSION}

A multiresidue method was developed for rapid and simultaneous determination of 9 organochlorines pesticides, one synthetic pyrithriod (fenopropathrin) and 7 congeners of PCBs compounds in fish by a modified procedure and GC-ECD analysis. The whole analytical procedure was validated according to European Union SANCO/12495/2011 guidelines. Furthermore, the method proved to be simple and gave quantitative results for the assayed analytes, providing good validation parameters, such as linearity, limits of detection and quantification and precision. The uncertainties values obtained for each pesticide were below $50 \%$ at all the fortification levels, which complies with the requirements of SANCO/12495/2011 document. The applicability of the method was demonstrated by analysis of six fish samples. A good performance of the method was observed, allowing the reliable determination of the target compounds in real samples. Finally, the results presented in this investigation demonstrate that the validated method is feasible to be applied in pesticide routine analysis carried out. 


\section{REFERENCES}

Addison R. F., D. C. Muir, M. G. Ikonomou, L. Harwood, T. G. Smith and J. Alikamik (2013). Temporal trends in "legacy" organochlorine contaminants in blubber of ringed seals (Phoca hispida) from Ulukhaktok, NT, Canada between 1972 and 2010. Sci. Total Environ., 3: 564-576.

ATSDR(Agency for Toxic Substances, Disease Registry). (2002). Toxicological profile for DDD/DDT/DDE. Atlanta, GA, USA: US Department of Health and Human Services, Public Health Service.

Bourgeon S., E. K. Leat. R. W. Furness, K., Borga, S. A. Hanssen and J. O. Bustnes (2013). Dietary versus maternal sources of organochlorines in top predator seabird chicks: an experimental approach. Environ Sci. Technol., 47: 5963-70.

Codex Alimentarius (1993). Vol. 2, $2^{\text {nd }}$ ed. section a, pages: 391-404.

EFSA (European Food Safety Authority). (2005). Opinion of the scientific panel on contaminants in the food chain on a request from the commission related to the presence of non dioxin-like polychlorinated biphenyls (PCB) in feed and food, adopted on 8 November. EFSA J., 284:1-137.

El- Nemr, A., T. O. Said, A. K. El- Sikaily and A. M. A. Abd-Allah (2003). Polychlorinated biphenyls and chlorinated pesticides in mussels collected from Egyptian Mediterranean coast. Bull. Environ. Contam. Toxicol., 71:290-297.

EURACHEM (2000). CITAC Guide CG 4. "Quantifying Uncertainty in Analytical Measurement", English Edition, Second edition, ISBN 0948926155.

Fleming L. E., K. Broad, A. Clement, E. Dewailly, S. Elmir and A. Knap (2006). Oceans and human health: emerging public health risk in the marine environment. Mar. Pollut. Bull.; 53:545-560.

Gioia, R., A. J. Akindele, S. A. Adebusoye, K. A. Asante, S. Tanabe and A. Buekens (2013). Polychlorinated biphenyls (PCBs) in Africa: a review of environmental levels. Environ. Sci. Pollut, Res., 33:340-351

Hamlin H. J. and L. J. Guillette, Jr. (2010). Birth defects in wildlife: the role of environmental contaminants as inducers of reproductive and developmental dysfunction. Syst. Biol. Reprod Med.,56: 113-121.

Jiries, A. B., F. M. Al Nasir and F. Beese (2002). Pesticide and heavy metals residue in wastewater, soil and plants in wastewater disposal site near Al-lajoun Valley, Karak/Jordan. Water Air Soil Pollut., 133: 97- 107.

Olafsdottir K.; Petersen A. E.; Magnusdottir E. V.; Bjornsson T. and Johannesson T. (2001). Persistent organochlorine levels in six prey species of the gyrfalcon Falco rusticolus in Iceland. Environ. Pollut., 112:245-251.

Pesticide Analytical Manual (1994). Vol.1. 3rd Edition, Section 304, Method No.E1-C1-C2. US, FDA.

Ryan, M . J., G. A. Stern, K. A. Kidd, M. V. Croft, S. Gewurtz and M. Diamond (2013). Biotic interactions in temporal trends (1992-2010) of organochlorine contaminants in the aquatic food web of Lake Laberge, Yukon Territory. Sci. Total Environ., 443:80-92. 
Safe S. H. (1994). Polychlorinated biphenyls (PCBs): environmental impact, biochemical and toxic responses, and implications for risk assessment. Crit Rev Toxicol., 24: 87-149.

Salah El-Dien, W. M. and I. N. Nasr (2004). Study of some organochlorine, pyrethroids and organophosphorus pesticide residues in fresh water crayfish (Procambarus clarkii). J Egypt Vet Med Ass., 64:41-51.

SANCO/12495 (2011). Method validation and quality control procedures for pesticide residues analysis in food and feed. [C.F. http://ec.europa.eu/food/plant/protection/recources/qualcontrol_en.pdf, 2012 (accessed 10.09.13)].

Schuster, J. K., R. Gioia, C. Moeckel, T. Agarwal, T. D. Bucheli and K. Breivik (2011). Has the burden and distribution of PCBs and PBDEs changed in European background soils between 1998 and 2008 Implications for sources and processes. Environ. Sci. Technol., 45: 7291-7297.

Sormo, E. G., H. J. S. Larsen, G. M. Johansen, J. U. Skaare and B. M. Jens sen (2009). Immunotoxicity of polychlorinated biphenyls (PCB) in freeranging Gray Seal pups with special emphasis on dioxin-like congeners. J Toxicol. Environ. Health, 72:266-276.

Storelli, M. M. (2008). Potential human health risks from metals $(\mathrm{Hg}, \mathrm{Cd}$, and $\mathrm{Pb}$ ) and polychlorinated biphenyls (PCBs) via seafood consumption: estimation of target hazard quotients (THQs) and toxic equivalents (TEQs). Food Chem. Toxicol., 46(8):2782-2788.

WHO (World Health Organization) (1999). Basic food safety for healthworkers, Geneva.[C.F.http://www.who.int/foodsafety/publications/c apacity/healthworkes/en/index. html]. 


$$
\text { الملخص العربي }
$$

\title{
تطوير و تقييم طريقة متعددة لتقدير متبقيات المبيدات الكلورنية و المركبات ثنائية
}

\section{الفينول متعددة الكلور فى الأغذية الدهنية}

\author{
عماد عطا الله و عبير الجوهرى و سناء الصاوى و على على محمود \\ المعمل المركزى لتحليل متبقيات المبيدات و العناصر الثقيلة فى الأغذية
}

مركز البحوث الزراعية- وزارة الزراعة

تم تقييم طريقة متعددة للتقدير الكمى لتسعة مبيدات كلورنية و مبيد بيروثرويد صناعى و سبعة مشابهات

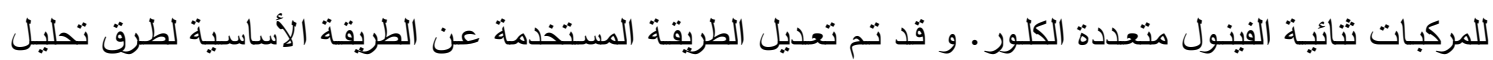
متبقيات المبيدات تبع ذلك استخدام أجهزة الكرماتوجراف الغاز المنصلة بالكاشف ماسك الإلكترونات. و و قد تم تقيبم

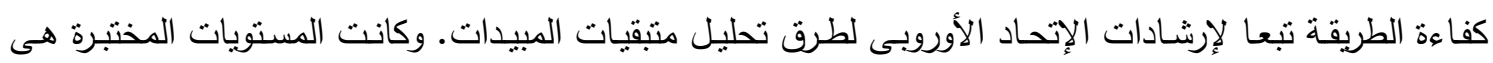

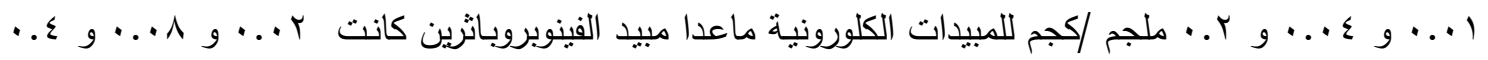

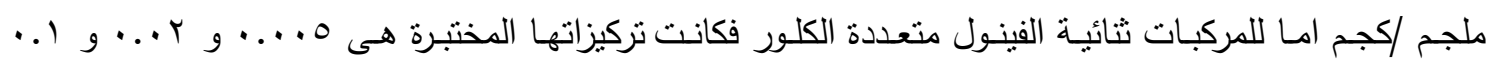
ملجم/كجم. و قد أظهرت الطريقة معايير مقبولة لكل من: أقل تركيز من منتقيات المبيدات يمكن قياسه (و التى هـ

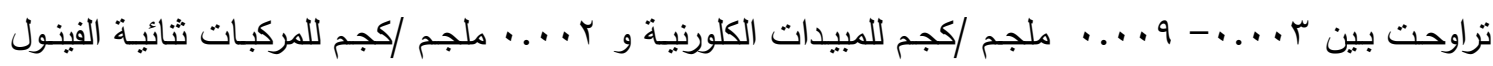

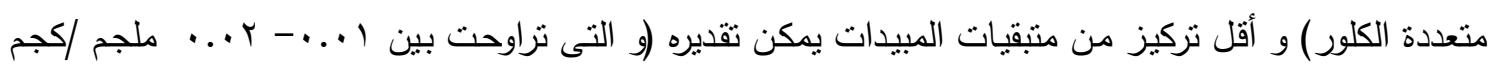
للمبيدات الكلورنية و ه . .. ملجم /كجم للمركبات ثنائية الفينول متعددة الكلور ) و متوسط معدل الإسترجاع لهذه لهنه

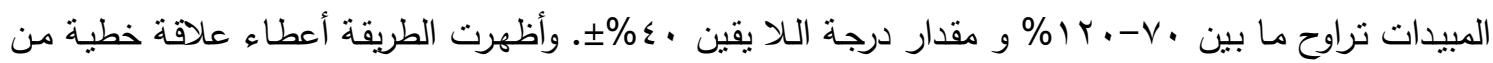

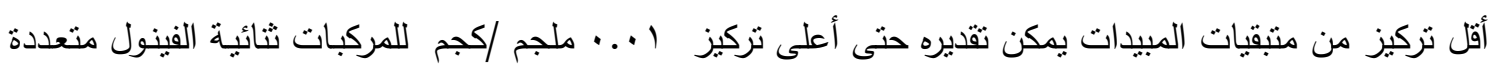

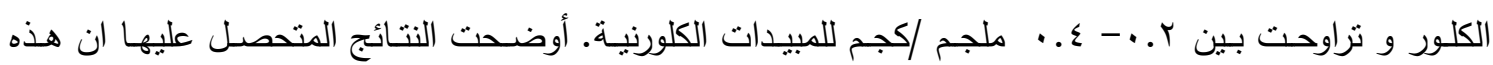
الطريقة بمكن تطبيقها عمليا. 
J. Adv. Agric. Res. (Fac. Agric. Saba Basha) 